\title{
Noninvasive population genetics: a review of sample source, diet, fragment length and microsatellite motif effects on amplification success and genotyping error rates
}

\author{
Thomas Broquet · Nelly Ménard · Eric Petit
}

Received: 13 February 2006 / Accepted: 1 March 2006/Published online: 3 June 2006

(C) Springer Science+Business Media B.V. 2006

\begin{abstract}
Noninvasive population genetics has found many applications in ecology and conservation biology. However, the technical difficulties inherent to the analysis of low quantities of DNA generally tend to limit the efficiency of this approach. The nature of samples and loci used in noninvasive population genetics are important factors that may help increasing the potential success of case studies. Here we reviewed the effects of the source of DNA (hair vs. faeces), the diet of focal species, the length of mitochondrial DNA fragments, and the length and repeat motif of nuclear microsatellite loci on genotyping success (amplification success and rate of allelic dropout). Locusspecific effects appeared to have the greatest impact, amplification success decreasing with both mitochondrial and microsatellite fragments' length, while error rates increase with amplicons' length. Dinucleotides showed best amplification success and lower error rates compared to longer repeat units. Genotyping success did not differ between hair- versus faeces-extracted DNA, and success in faeces-based analyses was not consistently influenced by the diet of focal species. While the great remaining variability among studies implies that other unidentified parameters are acting, results show that the careful choice of genetic markers may allow optimizing the success of noninvasive approaches.
\end{abstract}

T. Broquet $(\bowtie)$

Department of Ecology and Evolution, University of Lausanne, Ch-1015 Lausanne, Switzerland

e-mail: thomas.broquet@unil.ch

N. Ménard · E. Petit

UMR CNRS 6552, Ethologie-Evolution-Ecologie, Université

Rennes1, Station Biologique, Paimpont 35380, France
Keywords allelic dropout $\cdot$ amplification success · genotyping errors $\cdot$ low DNA $\cdot$ noninvasive

\section{Introduction}

Noninvasive population genetics is a set of field, laboratory and analytical techniques that allow studying the biology of natural populations without having even to observe individuals. It has thus been put forward as a chance for investigating the biology of elusive, rare and/ or endangered species (Piggott and Taylor 2003). Conservation biologists in particular have shown interest in these techniques, which for instance are now routinely used for the monitoring of brown bear populations in North America (Woods et al. 1999; Paetkau 2003). This example, however, is the exception rather than the rule, in particular because noninvasive population genetics is linked to numerous potential problems, especially at the stage of data production in the laboratory. In conservation genetics, most studies that use noninvasive samples rely on individual identifications based on genotypes at 5-15 hypervariable microsatellite loci (Taberlet and Luikart 1999). But in order to get accurate multilocus genotypes, DNA typing must be error free at all assessed loci. Unfortunately, noninvasively collected samples usually provide DNA extracts characterized by low target DNA concentration, low target DNA quality (degradation) and/ or contamination by alien DNA. Microsatellite typing has proven to be sensitive to all these kinds of problems, leading to genotyping errors and/or reduced amplification success. Thus, despite an undisputed attractiveness, noninvasive population genetics may not always be the most appropriate approach (Taberlet et al. 1999; Piggott and Taylor 2003). In particular, care should be taken 
regarding the financial and technical challenge involved in noninvasive genetics. Taberlet et al.'s (1999) advice is to perform a pilot study in order to estimate genotyping error rates. These rates can, in turn, be used to predict the number of times each sample must be amplified before accepting its genotype at a particular locus (Miller et al. 2002; Valière et al. 2002). Such pilot studies, however, do not address a number of important questions related to the potential success of surveys based on noninvasive sampling. Parameters such as fragment length, the repeat motif of microsatellite loci, the source of DNA or even the diet of the focal species may influence amplification and genotyping success. Evaluating their relative influence on genotyping and amplification success is not easy in pilot studies, because it requires sample sizes or experiments that are unavailable in such surveys. Another possibility, adopted in this review, is to use published results to test specific hypotheses in a comparative analysis.

DNA can be retrieved from various kinds of noninvasive samples (Höss et al. 1992; Sloane et al. 2000; Valière and Taberlet 2000; Vigilant et al. 2001), most studies being conducted with DNA extracted from shed hair or faeces. Shed hair are collected in the field either opportunistically (Vigilant et al. 2001) or using hair-traps (Mowat and Strobeck 2000; Sloane et al. 2000), and DNA is generally extracted from a single hair (e.g. Sloane et al. 2000) or from very few hair (1 to 3 hair: Constable et al. 2001) to avoid mixing DNA from different individuals (see Alpers et al. 2003 for discussion). Faeces are usually collected opportunistically and DNA is also extracted from a single sample (Vigilant et al. 2001). These two sources of DNA differ in three main characteristics that are relevant to subsequent genotyping results. First, much more DNA may be extracted from faeces (e.g. $38.4 \mathrm{ng}$ per extract, Morin et al. 2001) than from single hair (1 ng per single hair, Gagneux 1997), and amplification success and genotyping errors have been found to be sensible to template DNA concentration (Goossens et al. 1998; Morin et al. 2001). Second, besides template DNA, faeces contain a very large amount of alien DNA (from bacteria and from the diet). Amplification from alien DNA, however, can in a large extent be avoided by using specific primers, and will not be considered any further here (but see Bradley and Vigilant 2002). Finally, various molecules that can inhibit the polymerase chain reaction (PCR) may be present in faeces, a problem that is less likely with hair samples when using only hair roots (but see Nievergelt et al. 2002; Roon et al. 2003). Inhibition levels can vary with diet (Murphy et al. 2003), and most difficulties are met when working with faeces that contain plant remnants (Monteiro et al. 1997, D. Vallet, E. Petit and N. Ménard, unpublished manuscript).
Large enough data sets have offered the opportunity to test for locus or allele-specific effects, but results from surveys on single species appear contradictory. Frantz et al. (2003) found in a study on badger (Meles meles) that the different loci they used had heterogeneous error rates, but that allele length had no effect on these rates. A similar pattern was observed on Yellowstone grizzly (Miller and Waits 2003). In other studies, amplicon size has been shown to impact amplification success as well as allelic dropout rate (Morin et al. 2001; Buchan et al. 2005; Hoffman and Amos 2005). Locus specific effects could be explained, among other causes, by differences in the repeat motifs, dinucleotide microsatellites being for example more prone to slippage than tetranucleotides (Kruglyak et al. 1998).

In this comparative analysis, we specifically addressed the following hypotheses: First, we tested whether DNA extracted from shed hair is less easily amplified by PCR and leads to more genotyping errors than faecal DNA does. Second, we tested whether faecal DNA is less amplifiable when faeces contain plant material. Finally, we looked at locus specific effects, testing the hypotheses that longer amplicons amplify less often and yield more genotyping errors than shorter amplicons, and that microsatellite repeat motif affects amplification success and rates of genotyping error.

\section{Methods}

\section{Literature survey}

This review was based on population genetics studies involving noninvasive sampling of wild ranging species. We limited our search to studies based on hair or faeces samples, as other noninvasive sources of DNA (such as buccal swabs, urine, feathers ...) are more scarcely employed and would not allow comparing their respective efficiencies. We performed a search in the Current Contents database for any such paper published before 2004 to achieve an as exhaustive literature survey of the subject as possible (complete list of references available on request).

The focal species of each study was recorded, and was classified according to its diet either as a strict herbivore, a strict carnivore, or an omnivore. This classification was adopted in order to identify the cases where plant material was likely present in faeces. We then recorded the published genotyping success data associated to noninvasively collected hair or faeces. Mitochondrial DNA (MtDNA) and/or nuclear DNA (nucDNA, i.e. microsatellite) amplification success was recorded as the percentage of successful PCR (number of 
successful PCR relative to the total number of amplification attempts). Two kinds of genotyping errors may then be considered: allelic dropout (ADO), corresponding to the non-amplification of one allele of a heterozygous individual during a positive PCR, and false alleles (FA) resulting from slippage artefacts during the first cycles of the PCR, from cross-contaminations, or from other causes. Because different methods were used to calculate genotyping error rates among studies, we retained only ADO rates calculated as the number of observed dropouts (false homozygous genotypes) divided by the total number of successful amplifications of heterozygous genotypes, following Broquet and Petit (2004). When adequate raw data were available, ADO rates computed using other methods were recalculated using published data such as to allow for a comparison between studies. False alleles were not included in genotyping errors as their frequency may not reliably be compared among studies (see discussion in Broquet and Petit 2004). Hence in this paper genotyping errors refer to ADO only. When available, the length of the target DNA fragments (either mitochondrial or microsatellite sequences) and the repeat motif of microsatellite loci were also recorded. All literature data used in statistical analyses are presented in Appendix Tables 1-3.

If hair samples were used as DNA source, the sampling method was determined and only the data associated to the analysis of shed hair were retained (i.e. hair samples directly plucked on animals were not included here). We also retained genotyping data based on hair "trapped" on barbed wire (Roon et al. 2003), on glue tape (Sloane et al. 2000), on tree bark (Kohn et al. 1995) or other systems, assuming that such remote systems are more likely to collect hair at the end of their growth cycle. Such hair presenting less germinal tissue attached to their root would therefore be similar to naturally shed hair. Some hair-trapping systems could potentially allow collecting high-quality samples (i.e. similar to plucked hair), but we assumed that they would not do so constantly, and that hair containing less DNA would therefore be routinely used in downstream genotyping experiments (see Discussion).

Conditions of sampling, DNA extraction and genotyping procedures employed in each study were thoroughly surveyed, and all data potentially producing pseudo-replicates were eliminated from subsequent analyses. For instance only one data set was retained from studies involving a comparison between various laboratory protocols based on the same samples. In such cases, only the results obtained with the best method were included in our analyses. Similarly, genotyping success data based on a very small sample size were discarded (the smallest total number of independent amplifications used for quantifying genotyping success in the studies retained for the analyses was 9). Some published papers presented several datasets (i.e. different sets of samples corresponding to distinct species, or distinct studies involving the same focal species). In such cases the genotyping success data associated to each dataset were independently considered in the analyses. Each data set used in the analyses presented here were therefore obtained following a unique protocol, using one type of samples (either faeces or hair), and were generally directed at the study of a single species (with the exception of three studies of closely related species for which average genotyping success data were reported (Reed et al. 1997; Adams et al. 2003; Valière et al. 2003).

\section{Data analyses}

All analyses were performed using generalized linear models (GLM) implemented in R 2.2.0 (R Development Core Team, 2005). Error distribution in GLMs was always described using the binomial family (logit link function). Potential interpretation biases due to overdispersion were avoided by systematically using $F$-tests to select significant variables among models (e.g. Crawley 2005, p. 530).

The effect of the source of DNA (hair vs. faeces) was tested against mitochondrial or nuclear DNA amplification success and microsatellite genotyping error rate (models based on data reported in Appendix Table 1). We then tested for the effect of the diet (presence vs. absence of plant material in faeces, i.e. carnivore vs. herbivore+omnivore) on amplification success (data in Appendix Table 1). The amount of DNA contained in hair and faeces of different focal species may be influenced by the phylogenetic relationship among taxa. For this reason the analyses described above were performed using generalized estimating equations (GEE), which allow correcting for the non-independence of the data among taxa in a GLM framework (Paradis and Claude 2002). These analyses were performed in $\mathrm{R}$ using the package ape (Paradis et al. 2005).

Next we tested for the effect of MtDNA fragment length on amplification success using six studies in which fragments differing in length had been used (data in Appendix Table 2). Finally, the effects of microsatellite fragment length and motif on genotyping success were conjointly tested because of their potential relationship (data in Appendix Table 3). The origin of the data sets used in the analyses was also included as a factor in all models involving locus-specific data (i.e. tests based on Appendix Tables 2 and 3), therefore controlling for the effect of data clusters corresponding to distinct case studies usually 
involving different species and different genotyping methodologies.

\section{Results}

Amplification success of both MtDNA sequences and nuclear microsatellites appeared to vary greatly among studies, and was not influenced by the nature of the samples used for DNA extraction $(P>0.05$ in both cases), hair and faeces yielding comparable amplification rates (Fig. 1A). There may be a trend towards greater rates of $\mathrm{ADO}$ in hair-extracted DNA (Fig. 1B), but there is also a great variation in the frequency of ADO among studies, and the effect of the source of DNA was not statistically significant.

Similarly, the diet of focal species did not consistently affect the rate of successful PCR among studies (Fig. 2). Faecal samples collected from herbivore and omnivore species (i.e. containing plant material) did not provide less amplifiable DNA for microsatellite or MtDNA analyses $(P>0.05)$.

MtDNA and microsatellite amplification success were both correlated with the length of target DNA sequences $(P<0.001$ in both cases, Fig. 3A and B). Fragment length also appeared to significantly affect ADO rates when genotyping microsatellites $(P<0.001$, Fig. 3C). Independently of amplicon size, the effect of the repeat motif of microsatellite loci on amplification success was marginally significant ( $P=0.067$, Fig. 4A), while its effect on ADO rates was significant $(P<0.001)$. Shorter repeat motifs lead to higher amplification success and lesser allelic dropouts than longer ones (Fig. 4B).

\section{Discussion}

Amplification success showed no advantage of faecesover hair-extracted DNA, which is surprising regarding the amount of target DNA, expected to be usually higher in faecal samples (Morin et al. 2001). However, greater inhibitor concentrations on average in faecal samples may counterbalance this effect. It is also worth noting that the amount of DNA in hair samples critically depends on the number of hair used for DNA extraction, and also on the presence of follicles in hair roots, two factors that could not be disentangled in this comparative study. Results therefore suggest that the nature of samples (i.e. hair or faeces) is less important than the thorough optimization of extraction and genotyping protocols used with particular samples.

This is consistent with the absence of a clear effect of the nature of samples on ADO rates. The rate of error was on average slightly higher using hair samples (mean= $18.7 \%$ ) than using faeces (mean=11.3\%), and it is possible that this difference did not appear statistically significant due to a lack of statistical power (small sample size in GEE). However the overall probability of successfully amplifying a specific nuclear locus without dropout at the first attempt is $67.1 \%$ on average for faecal-extracted DNA and $65.2 \%$ for hair-extracted DNA (computed from mean values given in Fig. 1).

The analysis of an influence of diet did not support the idea that plant components negatively impact amplification success of faeces-extracted DNA. This may be accounted for by the use of adequate DNA extraction methods in most studies, which implies that working with faeces may involve additional lab work to identify what is the best
Fig. 1 (A) Amplification success of MtDNA and nucDNA (microsatellite loci) extracted from faeces $(\mathrm{F})$ vs. hair $(\mathrm{H})$ samples. (B) Rate of allelic dropout in faeces- (F) vs. hair-based $(\mathrm{H})$ microsatellite genotyping. Numbers correspond to mean values
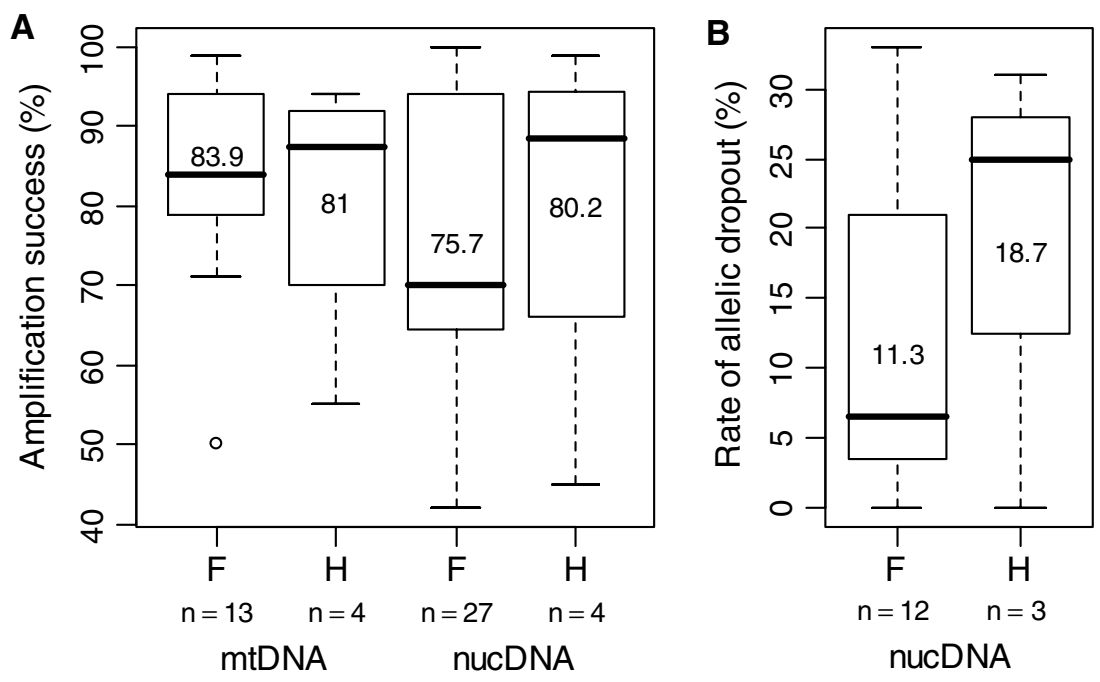


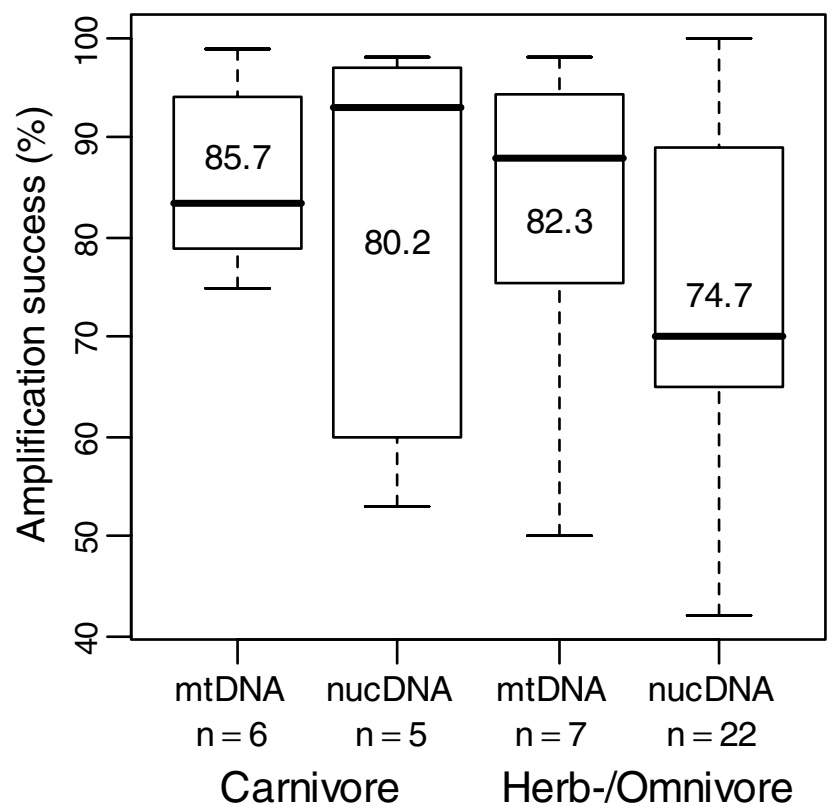

Fig. 2 Amplification success of MtDNA and NucDNA (microsatellites) extracted from carnivore vs. herbivore or omnivore species. Mean amplification rates are indicated

extraction method (Wasser et al. 1997) in contrary to shed hair that may be used as source of DNA in all species using slight variations of a simple extraction protocol (Walsh et al. 1991, but see Vigilant 1999 for alternatives). For instance, mitochondrial amplification success varied from 17 to $96 \%$ when extracting DNA from bat droppings using various methods (S. Puechmaille, G. Mathy and E. Petit, unpublished data).

Amplification success decreased with increasing amplicon length, except in one study in which a $245 \mathrm{bp}$ MtDNA fragment repeatedly appeared less amplifiable than a $418 \mathrm{bp}$ fragment in three species (Whittier et al. 1999). This case, however, seems to remain an exception and it may be partly resolved considering that the smaller fragment was amplified 1 year after the longer fragment. We thus discarded this study from our analyses. As the risk of ADO also increases with amplicon's length, using longer fragments may therefore in some cases result in a drastic decrease of overall genotyping success (see also Sefc et al. 2003; Buchan et al. 2005). Smaller MtDNA sequences may therefore be preferred in noninvasive genetic studies, provided enough variability is retained. When selecting from available microsatellite markers, "short" loci should also generally be preferred. The sensitivity of the rates of amplification and the rates of ADO to the length of a DNA fragment (independently of other factors) was calculated from the logistic models: for instance an amplification success of $73 \%$ (average rate of mtDNA amplification reported in the papers reviewed) is expected
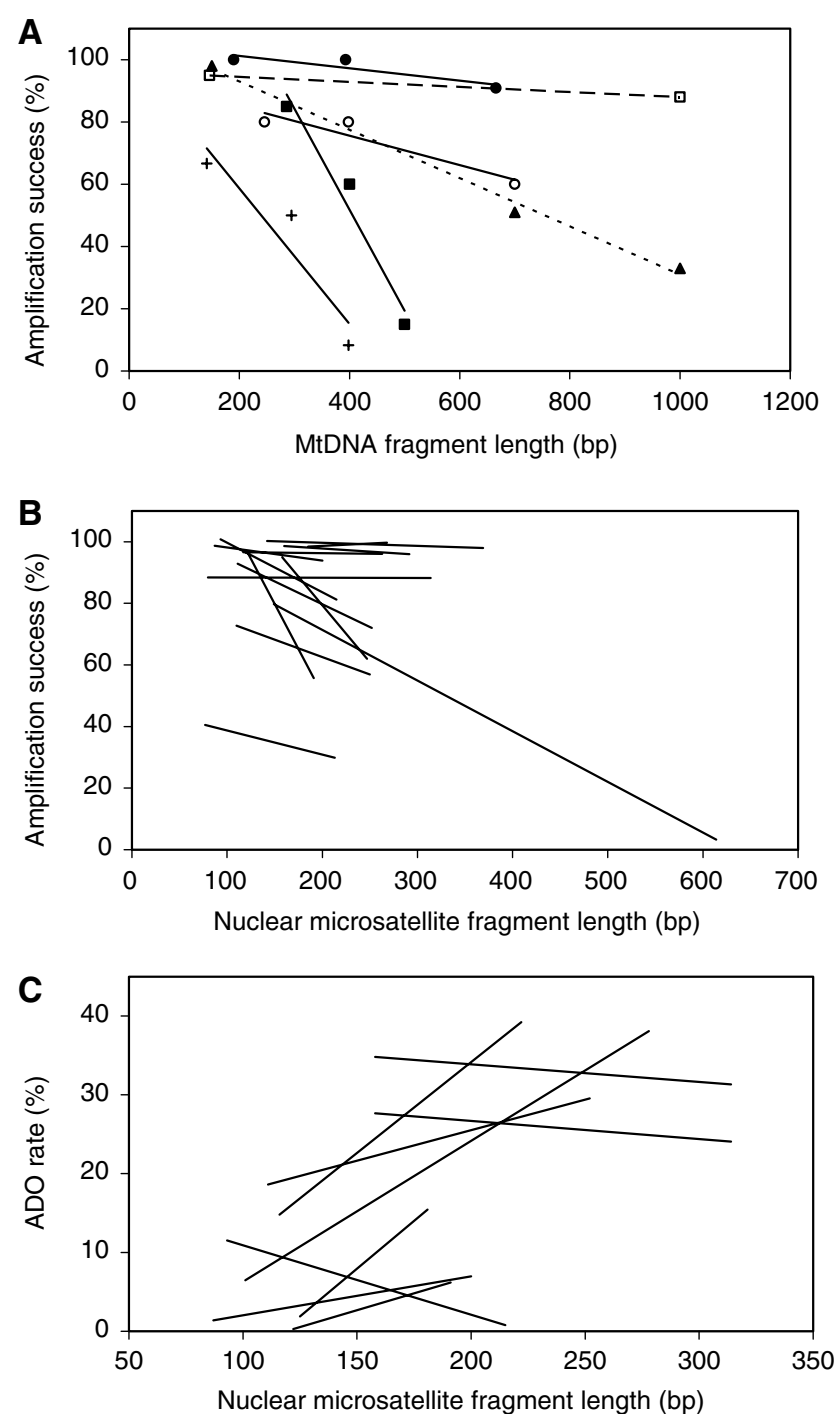

Fig. 3 (A) Relationship between amplification success and MtDNA fragment length in six noninvasive studies ( Papio ursinus, feces, Frantzen et al. 1998; \ Ursus Arctos, feces, Murphy et al. 2000; Pan troglodytes verus, hair, Vigilant 1999; + Ursus arctos, feces, Kohn et al 1995; $\square$ Ursus arctos, hair, Roon et al. 2003; $\bigcirc$ Ursus americanus, feces, Wasser et al. 1997). (B) Relationship between amplification success and microsatellite fragment length in 13 noninvasive studies (identified by superscript $\mathrm{c}$ in Appendix Table 3 ). For clarity purpose only regression lines are shown (each line corresponds to a study). (C) Relationship between rate of allelic dropout and microsatellite fragment length in 10 noninvasive studies (identified by superscript $d$ in Appendix Table 3)

to drop to $64 \%$ as a result of an increase of $100 \mathrm{bp}$ in MtDNA sequence length. Similarly, a rate of microsatellite amplification of $80 \%$ would decrease to $71 \%$, and a rate of ADO of $20 \%$ would increase to $26 \%$ when microsatellite fragment length is increased by $100 \mathrm{bp}$.

Our comparative study allowed us disentangling the effects of fragment length and repeat motif for microsatellites. Results indicate that dinucleotides should be preferred to longer repeat units: both the amplification 


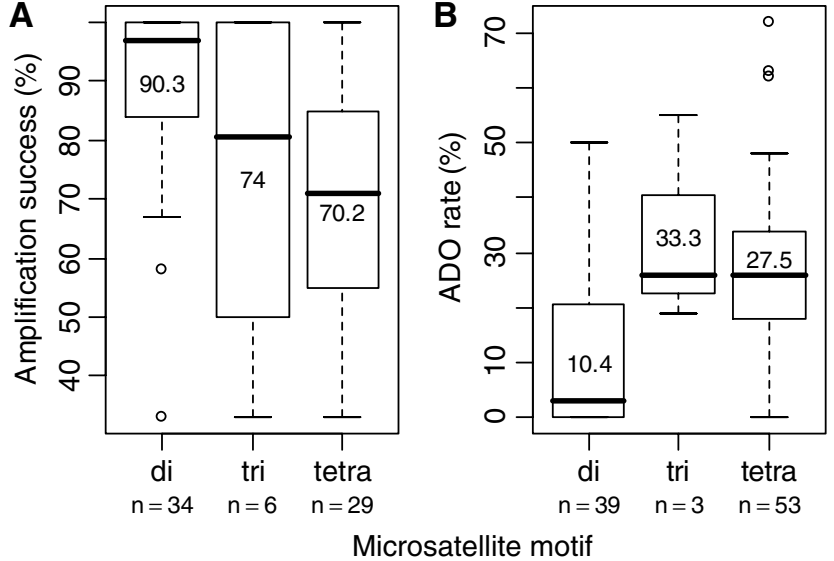

Fig. 4 Microsatellite amplification success and rate of allelic dropout of di-, tri- and tetra-nucleotides in noninvasive genetic studies. Mean rates are indicated

success and the genotyping error rates are best for these markers, the probability of amplifying a heterozygote genotype without dropout at the first attempt being $81 \%$ on average for dinucleotides versus about $50 \%$ for tri- and tetranucleotides (computed from values given on Fig. 4).

These general statements do not preclude the importance of other locus characteristics (variability, readability, multiplexing possibilities) when planning genotyping experiments. It is worth noting here that, for instance, the higher slippage propensity of dinucleotides (Kruglyak et al. 1998) leads to increased levels of PCR-generated shadow bands and hence, false alleles, which in some cases make dinucleotide microsatellite amplification patterns less easily and reliably read than amplification patterns of tri- or tetranucleotides (Taberlet and Luikart 1999). Also, as suggested by Hoffman and Amos (2005), the variability of microsatellite loci (expressed as gene diversity $\mathrm{He}$ ) appeared to have a small but significant positive effect on the risk of allelic dropout (but not on amplification success) in the studies reviewed here, independently of amplicon length and repeat motif (a 10\% increase in $\mathrm{He}$ would increase ADO rate from 20 to $22.2 \%$, data not shown). There is no obvious reason why the variability of a locus should affect its rate of dropout. One hypothesis (that remains to be tested) is that if smaller DNA fragments are more consistently amplified than bigger ones (as suggested by the short allele dominance hypothesis: Wattier et al. 1998, and by our results), then an increase in the difference in allele size within heterozygous individuals will result in an increased risk of ADO. Since the expected difference in size among pairs of alleles at any given locus depends on its variability (namely its distribution of allelic frequencies), ADO rates may appear indirectly correlated to gene diversity $\mathrm{He}$.

Overall, our results show that both the effects of diet and DNA source are limited when compared to locus characteristics, which have quantitatively a more important influence on the success of noninvasive genetic surveys. Variability of genotyping success among studies was also significant in all models tested, suggesting that other parameters specific to each study and not identified here are also acting.

Acknowledgements We are grateful to E. Paradis, J.-S. Pierre, N. Salamin and J. Yearsley for answering our questions on generalized linear models and generalized estimating equations. We thank authors of the papers reviewed that gave us some details on their respective studies. We thank also J. Jaquiéry and two anonymous reviewers for comments on a previous draft.

\section{Appendix}

Table 1 Literature review of estimates of amplification success and error rates (formulas according to Broquet and Petit 2004)

\begin{tabular}{|c|c|c|c|c|c|c|}
\hline Reference & Species (or group) & Diet & $\begin{array}{l}\text { Source } \\
\text { of DNA }\end{array}$ & $\begin{array}{l}\text { MtDNA pcr } \\
\text { success }(\%)^{\mathrm{a}, \mathrm{b}}\end{array}$ & $\begin{array}{l}\text { NucDNA pcr } \\
\text { success }(\%)^{\mathrm{a}, \mathrm{b}}\end{array}$ & $\begin{array}{l}\mathrm{ADO} \\
\text { rate }(\%)^{\mathrm{a}, \mathrm{b}}\end{array}$ \\
\hline Adams et al. (2003) & Carnivora & $\mathrm{C}$ & $\mathrm{F}$ & 83.0 & & \\
\hline Bayes et al. (2000) & Papio cynocephalus & $\mathrm{O}$ & $\mathrm{F}$ & & 70.0 & 10.3 \\
\hline \multirow[t]{2}{*}{ Bradley et al. (2000) } & Pan troglodytes verus & $\mathrm{O}$ & $\mathrm{F}$ & & 82.0 & \\
\hline & Gorilla gorilla gorilla & $\mathrm{H}$ & $\mathrm{F}$ & & 56.0 & \\
\hline \multirow[t]{2}{*}{ Constable et al. (2001) } & Pan troglodytes schweinfurthii & $\mathrm{O}$ & $\mathrm{F}$ & & 71.0 & 33.3 \\
\hline & Pan troglodytes schweinfurthii & $\mathrm{O}$ & $\mathrm{H}$ & & 90.0 & 25.3 \\
\hline Fernando et al. (2003) & Elephas maximus & $\mathrm{H}$ & $\mathrm{F}$ & & 99.6 & 0.4 \\
\hline \multirow[t]{2}{*}{ Flagstad et al. (1999) } & Ovis aries & $\mathrm{H}$ & $\mathrm{F}$ & & 96.5 & 5.9 \\
\hline & Rangifer tarandus & $\mathrm{H}$ & $\mathrm{F}$ & & 95.0 & 4.2 \\
\hline \multirow{2}{*}{ Frantz et al. (2003) } & Meles meles & $\mathrm{O}$ & $\mathrm{F}$ & & $\sim 61$ & \\
\hline & Meles meles & $\mathrm{O}$ & $\mathrm{F}$ & & & 26.8 \\
\hline Frantzen et al. (1998) & Papio ursinus & $\mathrm{O}$ & $\mathrm{F}$ & 97.0 & 42.0 & \\
\hline Gagneux (1997) & Pan troglodytes & $\mathrm{O}$ & $\mathrm{H}$ & & & 31.3 \\
\hline Gerloff et al. (1995) & Pan paniscus & $\mathrm{O}$ & $\mathrm{F}$ & 66.0 & & \\
\hline Goossens et al. (2000) & Pongo pygmaeus abelii & $\mathrm{H}$ & $\mathrm{F}$ & & 65.0 & 4.2 \\
\hline \multirow[t]{2}{*}{ Huber et al. (2003) } & Lepus europaeus & $\mathrm{H}$ & $\mathrm{F}$ & & 96.3 & \\
\hline & Cervus elaphus & $\mathrm{H}$ & $\mathrm{F}$ & & 97.4 & \\
\hline
\end{tabular}


Table 1 continued

\begin{tabular}{|c|c|c|c|c|c|c|}
\hline Reference & Species (or group) & Diet & $\begin{array}{l}\text { Source } \\
\text { of DNA }\end{array}$ & $\begin{array}{l}\text { MtDNA pcr } \\
\text { success }(\%)^{\mathrm{a}, \mathrm{b}}\end{array}$ & $\begin{array}{l}\text { NucDNA pcr } \\
\text { success }(\%)^{\mathrm{a}, \mathrm{b}}\end{array}$ & $\begin{array}{l}\mathrm{ADO} \\
\text { rate }(\%)^{\mathrm{a}, \mathrm{b}}\end{array}$ \\
\hline Idaghdour et al. (2003) & Otis tarda & $\mathrm{O}$ & $\mathrm{F}$ & 70.6 & & \\
\hline Kohn et al. (1999) & Canis latrans & $\mathrm{C}$ & $\mathrm{F}$ & 79.0 & 96.6 & \\
\hline \multirow[t]{2}{*}{ Kohn et al. (1995) } & Ursus arctos & $\mathrm{O}$ & $\mathrm{F}$ & 50.0 & & \\
\hline & Ursus arctos & $\mathrm{O}$ & $\mathrm{H}$ & 93.7 & & \\
\hline Lathuillière et al. (2001) & Macaca sylvanus & $\mathrm{H}$ & $\mathrm{F}$ & & 70.0 & 3.0 \\
\hline Launhardt et al. (1998) & Presbytis entellus & $\mathrm{O}$ & $\mathrm{F}$ & & 70.0 & $\sim 6.8$ \\
\hline Lucchini et al. (2002) & Canis lupus & $\mathrm{C}$ & $\mathrm{F}$ & 84.0 & 53.0 & 18.0 \\
\hline Morin et al. (2001) & Pan troglodytes verus & $\mathrm{O}$ & $\mathrm{F}$ & & 79.0 & 24.0 \\
\hline Murphy et al. (2000) & Ursus arctos & $\mathrm{O}$ & $\mathrm{F}$ & 98.0 & 89.0 & \\
\hline Murphy et al. (2002) & Ursus arctos & $\mathrm{O}$ & $\mathrm{F}$ & 92.0 & 88.0 & \\
\hline Murphy et al. (2003) & Ursus arctos & $\mathrm{O}$ & $\mathrm{F}$ & 88.0 & 65.0 & \\
\hline Palomares et al. (2002) & Lynx lynx & $\mathrm{C}$ & $\mathrm{F}$ & 99 & & \\
\hline Parsons (2001) & Tursiops truncatus & $\mathrm{C}$ & $\mathrm{F}$ & & 98.1 & 0 \\
\hline Reed et al. (1997) & $\begin{array}{l}\text { Halichoerus grypus/ } \\
\text { Phoca vitulina }\end{array}$ & $\mathrm{C}$ & $\mathrm{F}$ & $\sim 75$ & $\sim 60$ & \\
\hline Roon et al. (2003) & Ursus arctos & $\mathrm{O}$ & $\mathrm{H}$ & $\sim 90$ & $\sim 99$ & \\
\hline Sloane et al. (2000) & Lasiorhinus krefftii & $\mathrm{H}$ & $\mathrm{H}$ & & 87.4 & 0 \\
\hline Smith et al. (2000) & Papio cynocephalus & $\mathrm{O}$ & $\mathrm{F}$ & & 53.0 & \\
\hline \multirow[t]{2}{*}{ Valière et al. (2003) } & $\begin{array}{l}\text { Canis lupus, C. familiaris, } \\
\text { Vulpes vulpes }\end{array}$ & $\mathrm{C}$ & $\mathrm{F}$ & 94.2 & & \\
\hline & $\begin{array}{l}\text { Canis lupus, C. familiaris, } \\
\text { Vulpes vulpes }\end{array}$ & $\mathrm{C}$ & $\mathrm{H}$ & 55 & & \\
\hline Vege and McCracken (2001) & Eptesicus fuscus & $\mathrm{C}$ & $\mathrm{F}$ & & 93.0 & 0 \\
\hline Vigilant (1999) & Pan troglodytes verus & $\mathrm{O}$ & $\mathrm{H}$ & 85.0 & 45.0 & \\
\hline Vigilant (2002) & Pan troglodytes verus & $\mathrm{O}$ & $\mathrm{F}$ & & $\sim 64$ & \\
\hline Wasser et al. (1997) & Ursus americanus & $\mathrm{O}$ & $\mathrm{F}$ & 80.0 & 67.0 & \\
\hline
\end{tabular}

aValues preceded by " $\sim$ " are not exact values but were evaluted from published graphics

${ }^{\mathrm{b}}$ Values in italic were recalculated using published data

Table 2 Literature review of estimates of MtDNA amplification success
aValues preceded by “ “" are not exact values but were evaluated from published graphics

\begin{tabular}{|c|c|c|c|c|}
\hline Reference & $\begin{array}{l}\text { Species or group } \\
\text { of species }\end{array}$ & Source of DNA & $\begin{array}{l}\text { Length of } \\
\text { fragment (bp) }\end{array}$ & $\begin{array}{l}\text { MtDNA pcr } \\
\text { success }(\%)^{\mathrm{a}}\end{array}$ \\
\hline Adams et al. (2003) & Carnivora & $\mathrm{F}$ & 200 & 83 \\
\hline Frantzen et al. (1998) & Papio ursinus & $\mathrm{F}$ & $\begin{array}{l}190 \\
393 \\
666\end{array}$ & $\begin{array}{r}100 \\
100 \\
91\end{array}$ \\
\hline Idaghdour et al. (2003) & Otis tarda & $\mathrm{F}$ & 452 & 71 \\
\hline Kohn et al. (1995) & Ursus arctos & $\mathrm{F}$ & $\begin{array}{l}141 \\
295 \\
398\end{array}$ & $\begin{array}{r}67 \\
50 \\
8\end{array}$ \\
\hline & & $\mathrm{H}$ & 398 & 94 \\
\hline Kohn et al. (1999) & Canis latrans & $\mathrm{F}$ & 398 & 79 \\
\hline Lucchini et al. (2002) & Canis lupus & $\mathrm{F}$ & 404 & 84 \\
\hline Murphy et al. (2000) & Ursus arctos & $\mathrm{F}$ & $\begin{array}{r}150 \\
700 \\
1000\end{array}$ & $\begin{array}{l}98 \\
51 \\
33\end{array}$ \\
\hline Murphy et al. (2002) & Ursus arctos & $\mathrm{F}$ & 146 & 92 \\
\hline Murphy et al. (2003) & Ursus arctos & $\mathrm{F}$ & 146 & 88 \\
\hline Reed et al. (1997) & $\begin{array}{l}\text { Halichoerus } \\
\text { grypus/Phoca vitulina }\end{array}$ & $\mathrm{F}$ & 520 & $\sim 75$ \\
\hline Roon et al. (2003) & Ursus arctos & $\mathrm{H}$ & $\begin{array}{r}146 \\
1000\end{array}$ & $\begin{array}{l}\sim 95 \\
\sim 88\end{array}$ \\
\hline Vigilant (1999) & Pan troglodytes verus & $\mathrm{H}$ & $\begin{array}{l}286 \\
400 \\
500\end{array}$ & $\begin{array}{l}85 \\
60 \\
15\end{array}$ \\
\hline Wasser et al. (1997) & Ursus americanus & $\mathrm{F}$ & $\begin{array}{l}246 \\
398 \\
700\end{array}$ & $\begin{array}{l}80 \\
80 \\
60\end{array}$ \\
\hline
\end{tabular}


Table 3 Literature review of estimates of nuclear microsatellite loci genotyping success (formulas according to Broquet and Petit 2004)

\begin{tabular}{|c|c|c|c|c|c|c|}
\hline Reference & Species & $\begin{array}{l}\text { Source of } \\
\text { DNA }\end{array}$ & $\begin{array}{l}\text { PCR } \\
\text { success } \\
(\%)\end{array}$ & $\begin{array}{l}\text { Length of } \\
\text { fragment } \\
\text { (bp) }\end{array}$ & Motif & $\begin{array}{l}\mathrm{ADO} \\
\text { rate } \\
(\%)^{\mathrm{a}, \mathrm{b}}\end{array}$ \\
\hline \multirow[t]{8}{*}{ Bayes et al. $(2000)^{\mathrm{c}}$} & \multirow[t]{8}{*}{ Papio anubis } & \multirow[t]{8}{*}{$\mathrm{F}$} & & 163 & Tetra & 4.3 \\
\hline & & & & 125 & Tetra & 3.9 \\
\hline & & & & 181 & $\mathrm{Di}$ & 22.7 \\
\hline & & & & 161 & Di & 9.4 \\
\hline & & & & 174 & Tetra & 6.7 \\
\hline & & & & 170 & $\mathrm{Di}$ & 6.1 \\
\hline & & & & 167 & Tetra & 15.8 \\
\hline & & & & 169 & $\mathrm{Di}$ & 21.4 \\
\hline \multirow[t]{2}{*}{ Bradley et al. $(2000)^{\mathrm{d}}$} & \multirow{2}{*}{$\begin{array}{l}\text { Pan troglodytes } \\
\text { verus }\end{array}$} & \multirow[t]{2}{*}{$\mathrm{F}$} & 62 & 247 & Tetra & \\
\hline & & & 95 & 158 & Tetra & \\
\hline \multirow[t]{16}{*}{ Constable et al. $(2001)^{\mathrm{c}}$} & \multirow{16}{*}{$\begin{array}{l}\text { Pan troglodytes } \\
\text { schweinfurthii }\end{array}$} & \multirow[t]{16}{*}{$\mathrm{H}$} & & 218 & Tetra & 14 \\
\hline & & & & 177 & Tetra & 32 \\
\hline & & & & 190 & Tetra & 42 \\
\hline & & & & 158 & Tetra & 26 \\
\hline & & & & 290 & Tetra & 30 \\
\hline & & & & 239 & Tetra & 20 \\
\hline & & & & 255 & Tetra & 15 \\
\hline & & & & 259 & Tetra & 21 \\
\hline & & & & 283 & Tetra & 39 \\
\hline & & & & 314 & Tetra & 35 \\
\hline & & & & 283 & Tetra & 24 \\
\hline & & & & 290 & Tetra & 15 \\
\hline & & & & 165 & Tetra & 29 \\
\hline & & & & 271.5 & Tetra & 30 \\
\hline & & & & 271 & Tetra & 13 \\
\hline & & & & 213 & Tri & 26 \\
\hline \multirow[t]{16}{*}{ Constable et al. $(2001)^{\mathrm{c}}$} & \multirow{16}{*}{$\begin{array}{l}\text { Pan troglodytes } \\
\text { schweinfurthii }\end{array}$} & \multirow[t]{16}{*}{$\mathrm{F}$} & & 218 & Tetra & 24 \\
\hline & & & & 177 & Tetra & 48 \\
\hline & & & & 190 & Tetra & 25 \\
\hline & & & & 158 & Tetra & 33 \\
\hline & & & & 290 & Tetra & 29 \\
\hline & & & & 239 & Tetra & 19 \\
\hline & & & & 255 & Tetra & 40 \\
\hline & & & & 259 & Tetra & 45 \\
\hline & & & & 283 & Tetra & 39 \\
\hline & & & & 314 & Tetra & 15 \\
\hline & & & & 283 & Tetra & 29 \\
\hline & & & & 290 & Tetra & 24 \\
\hline & & & & 165 & Tetra & 18 \\
\hline & & & & 271.5 & Tetra & 63 \\
\hline & & & & 271 & Tetra & 21 \\
\hline & & & & 213 & Tri & 55 \\
\hline \multirow[t]{6}{*}{ Fernando et al. $(2003)^{\mathrm{d}}$} & \multirow[t]{6}{*}{ Elephas maximus } & \multirow[t]{6}{*}{$\mathrm{F}$} & 100 & 144 & Tri & \\
\hline & & & 100 & 220 & Tri & \\
\hline & & & 100 & 246 & Tetra & \\
\hline & & & 97.5 & 369 & Tetra & \\
\hline & & & 100 & 149 & $\mathrm{Di}$ & \\
\hline & & & 100 & 142 & $\mathrm{Di}$ & \\
\hline Flagstad et al. (1999) & Rangifer tarandus & $\mathrm{F}$ & 90 & 171 & & 0 \\
\hline & & & 80 & 215 & & 0 \\
\hline & & & 100 & 93 & $\mathrm{Di}$ & 0 \\
\hline & & & 100 & 97 & $\mathrm{Di}$ & 0 \\
\hline & & & 100 & 106 & Di & 50 \\
\hline & & & 100 & 94 & $\mathrm{Di}$ & 0 \\
\hline Flagstad et al. (1999) & Ovis aries & $\mathrm{F}$ & 92.9 & 137 & & 5.3 \\
\hline & & & 97.6 & 87 & Di & 0 \\
\hline & & & 100 & 118 & $\mathrm{Di}$ & 0 \\
\hline & & & 90.5 & 184 & Di & 7.1 \\
\hline & & & 100 & 120 & $\mathrm{Di}$ & 6.7 \\
\hline & & & 97.6 & 200 & Di & 5.3 \\
\hline
\end{tabular}


Table 3 continued

\begin{tabular}{|c|c|c|c|c|c|c|}
\hline Reference & Species & $\begin{array}{l}\text { Source of } \\
\text { DNA }\end{array}$ & $\begin{array}{l}\text { PCR } \\
\text { success } \\
(\%)\end{array}$ & $\begin{array}{l}\text { Length of } \\
\text { fragment } \\
\text { (bp) }\end{array}$ & Motif & $\begin{array}{l}\mathrm{ADO} \\
\text { rate } \\
(\%)^{\mathrm{a}, \mathrm{b}}\end{array}$ \\
\hline \multirow[t]{7}{*}{ Frantz et al. $(2003)^{c}$} & \multirow[t]{7}{*}{ Meles meles } & \multirow[t]{7}{*}{$\mathrm{F}$} & & 196 & Di & 47.7 \\
\hline & & & & 143 & $\mathrm{Di}$ & 25.6 \\
\hline & & & & 222 & Di & 29.7 \\
\hline & & & & 116 & $\mathrm{Di}$ & 10.6 \\
\hline & & & & 134 & $\mathrm{Di}$ & 20 \\
\hline & & & & 122 & $\mathrm{Di}$ & 14 \\
\hline & & & & 183 & Di & 26.1 \\
\hline \multirow[t]{3}{*}{ Frantzen et al. (1998) } & \multirow{3}{*}{$\begin{array}{l}\text { Papio cynocepha- } \\
\text { lus } \\
\text { ursinus }\end{array}$} & \multirow[t]{3}{*}{$\mathrm{F}$} & 86.4 & 149 & & \\
\hline & & & 31.8 & 365 & & \\
\hline & & & 9.1 & 614 & & \\
\hline \multirow[t]{11}{*}{ Gagneux et al. (1997) } & \multirow[t]{11}{*}{ Pan troglodytes } & \multirow[t]{11}{*}{$\mathrm{H}$} & & 220 & Tri & 32.1 \\
\hline & & & & & Tri & 22.6 \\
\hline & & & & & $\mathrm{Di}$ & 43.5 \\
\hline & & & & 204 & $\mathrm{Di}$ & 25.3 \\
\hline & & & & 178 & $\mathrm{Di}$ & 27.5 \\
\hline & & & & 143 & Di & 26.8 \\
\hline & & & & & Tetra & 34.6 \\
\hline & & & & & Tetra & 31.4 \\
\hline & & & & & Tetra & 36 \\
\hline & & & & & Tetra & 29.2 \\
\hline & & & & & Di & 42.6 \\
\hline Goossens et al. (2000) & $\begin{array}{l}\text { Pongo pygmaeus } \\
\text { abelii }\end{array}$ & $\mathrm{F}$ & 65 & & Tetra & 4.2 \\
\hline \multirow[t]{4}{*}{ Huber et al. $(2003)^{d}$} & \multirow[t]{4}{*}{ Lepus europaeus } & \multirow[t]{4}{*}{$\mathrm{F}$} & 97.2 & 117 & & \\
\hline & & & 96.6 & 182 & & \\
\hline & & & 96.4 & 263 & & \\
\hline & & & 95.2 & 172 & & \\
\hline \multirow[t]{3}{*}{ Huber et al. $(2003)^{\mathrm{d}}$} & \multirow[t]{3}{*}{ Cervus elaphus } & \multirow[t]{3}{*}{$\mathrm{F}$} & 95.6 & 291.5 & $\mathrm{Di}$ & \\
\hline & & & 98.2 & 160 & $\mathrm{Di}$ & \\
\hline & & & 98.2 & 220.5 & $\mathrm{Di}$ & \\
\hline \multirow{3}{*}{$\begin{array}{l}\text { Lathuillière } \\
(2001)^{\mathrm{c}, \mathrm{d}}\end{array}$} & Macaca sylvanus & $\mathrm{F}$ & 100 & 122 & $\mathrm{Di}$ & 0 \\
\hline & & & 75 & 148 & $\mathrm{Di}$ & 3 \\
\hline & & & 58 & 191 & Di & 6 \\
\hline Launhardt et al. (1998) & Presbytis entellus & $\mathrm{F}$ & & 124 & $\mathrm{Di}$ & $\sim 6.8$ \\
\hline Lucchini et al. $(2002)^{c}$ & Canis lupus & $\mathrm{F}$ & & 101 & Di & 3 \\
\hline & & & & 208 & Di & 29 \\
\hline & & & & 206 & Di & 33 \\
\hline & & & & 278 & Tetra & 31 \\
\hline & & & & 115 & Tetra & 15 \\
\hline & & & & 102 & Tetra & 0 \\
\hline Morin et al. $(2001)^{\mathrm{c}, \mathrm{d}}$ & Pan troglodytes & $\mathrm{F}$ & 75 & 244 & Tetra & 15 \\
\hline & verus & & 74 & 191 & Tetra & 31 \\
\hline & & & 84 & 182 & Tetra & 35 \\
\hline & & & 88 & 138 & Tetra & 12 \\
\hline & & & 80 & 252 & Tetra & 34 \\
\hline & & & 97 & 158 & Tetra & 26 \\
\hline & & & 71 & 196 & Tetra & 27 \\
\hline & & & 80 & 180 & Tetra & 19 \\
\hline & & & 65 & 247 & Tetra & 32 \\
\hline & & & 85 & 132 & Tetra & 20 \\
\hline & & & 92 & 111 & Tri & 19 \\
\hline & & & 87 & 162 & Tetra & 23 \\
\hline & & & 92 & 180 & Tetra & 21 \\
\hline Murphy et al. (2000) & Ursus arctos & $\mathrm{F}$ & 89 & 200 & $\mathrm{Di}$ & \\
\hline Murphy et al. (2002) & Ursus arctos & $\mathrm{F}$ & 88 & 190 & $\mathrm{Di}$ & \\
\hline Murphy et al. (2003) & Ursus arctos & $\mathrm{F}$ & 65 & 190 & $\mathrm{Di}$ & \\
\hline Roon et al. $(2003)^{\mathrm{d}}$ & Ursus arctos & $\mathrm{H}$ & $\sim 100$ & 268 & $\mathrm{Di}$ & \\
\hline & & & $\sim 99$ & 185 & $\mathrm{Di}$ & \\
\hline & & & $\sim 98$ & 214 & $\mathrm{Di}$ & \\
\hline Sloane et al. $(2000)^{\mathrm{c}, \mathrm{d}}$ & Lasiorhinus krefftii & $\mathrm{H}$ & 88 & 193 & $\mathrm{Di}$ & 0 \\
\hline
\end{tabular}


Table 3 continued

\begin{tabular}{|c|c|c|c|c|c|c|}
\hline Reference & Species & $\begin{array}{l}\text { Source of } \\
\text { DNA }\end{array}$ & $\begin{array}{l}\text { PCR } \\
\text { success } \\
(\%)\end{array}$ & $\begin{array}{l}\text { Length of } \\
\text { fragment } \\
\text { (bp) }\end{array}$ & Motif & $\begin{array}{l}\mathrm{ADO} \\
\text { rate } \\
(\%)^{\mathrm{a}, \mathrm{b}}\end{array}$ \\
\hline & & & 88 & 200 & Di & 0 \\
\hline & & & 100 & 99 & Di & 0 \\
\hline & & & 92 & 145 & Di & 0 \\
\hline & & & 96 & 159 & Di & 0 \\
\hline & & & 92 & 126 & Di & 0 \\
\hline & & & 84 & 158 & Di & 0 \\
\hline & & & 84 & 207 & Di & 0 \\
\hline & & & 84 & 138 & Di & 0 \\
\hline & & & 76 & 80 & Di & 0 \\
\hline & & & 80 & 303 & Di & 0 \\
\hline & & & 96 & 314 & Di & 0 \\
\hline \multirow[t]{5}{*}{ Smith et al. (2000) } & Papio cynocepha- & $\mathrm{F}$ & 47 & & Tetra & 72 \\
\hline & lus & & 55 & & Tetra & 47 \\
\hline & & & 67 & & $\mathrm{Di}$ & 28 \\
\hline & & & 52 & & Tetra & 46 \\
\hline & & & 44 & & Tetra & 62 \\
\hline \multirow[t]{5}{*}{${\text { Vigilant }(1999)^{\mathrm{d}}}^{\mathrm{d}}$} & Pan troglodytes & $\mathrm{H}$ & 33 & 90 & $\mathrm{Di}$ & \\
\hline & verus & & 50 & 77 & Tri & \\
\hline & & & 33 & 213 & Tri & \\
\hline & & & 33 & 138 & Tetra & \\
\hline & & & 33 & 128 & Tetra & \\
\hline \multirow[t]{8}{*}{ Vigilant $(2002)^{\mathrm{d}}$} & Pan troglodytes & $\mathrm{F}$ & $\sim 69$ & 110 & Tri & \\
\hline & verus & & $\sim 74$ & 135 & Tetra & \\
\hline & & & $\sim 70$ & 160 & Tetra & \\
\hline & & & $\sim 69$ & 175 & Tetra & \\
\hline & & & $\sim 65$ & 250 & Tetra & \\
\hline & & & $\sim 57$ & 245 & Tetra & \\
\hline & & & $\sim 53$ & 247 & Tetra & \\
\hline & & & $\sim 52$ & 205 & Tetra & \\
\hline Wasser et al. (1997) & Ursus americanus & $\mathrm{F}$ & $\sim 67$ & 256 & $\mathrm{Di}$ & \\
\hline
\end{tabular}

\section{References}

Adams JR, Kelly BT, Waits LP (2003) Using faecal DNA sampling and GIS to monitor hybridization between red wolves (Canis rufus) and coyotes (Canis latrans). Mol Ecol 12:21752186

Alpers DL, Taylor AC, Bellman SA, Sherwin WB (2003) Pooling hair samples to increase DNA yield for PCR. Conserv Genet 4:779-788

Bayes MK, Smith KL, Alberts SC, Altmann J, Bruford MW (2000) Testing the reliability of microsatellite typing from faecal DNA in the savannah baboon. Conserv Genet 1:173-176

Bradley BJ, Vigilant L (2002) False alleles derived from microbial DNA pose a potential source of error in microsatellite genotyping of DNA from faeces. Mol Ecol Notes 2002:602-605

Bradley BJ, Boesch C, Vigilant L (2000) Identification and redesign of human microsatellite markers for genotyping wild chimpanzee (Pan troglodytes verus) and gorilla (Gorilla gorilla gorilla) DNA from feces. Conserv Genet 1:289-292

Broquet T, Petit E (2004) Quantifying genotyping errors in noninvasive population genetics. Mol Ecol 13:3601-3608

Buchan JC, Archie EA, Van Horn RC, Moss CJ, Alberts SC (2005) Locus effects and sources of error in noninvasive genotyping. Mol Ecol Notes 5(3): 680-683

Constable JL, Ashley MV, Goodall J, Pusey AE (2001) Noninvasive paternity assignment in Gombe chimpanzees. Mol Ecol 10:1279-1300
Crawley MJ (2005) Statistical computing: an introduction to data analysis using S-Plus. John Wiley and sons Ltd, Chichester

Fernando P, Vidya TNC, Rajapakse C, Dangolla A, Melnick DJ (2003) Reliable noninvasive genotyping: fantasy or reality? J Hered 94:115-123

Flagstad Ø, Røed K, Stacy JE, Jakobsen KS (1999) Reliable noninvasive genotyping based on excremental PCR of nuclear DNA purified with a magnetic bead protocol. Mol Ecol 8:879-883

Frantz AC, Pope LC, Carpenter PJ, Roper TJ, Wilson GJ, Delahay RJ, Burke T (2003) Reliable microsatellite genotyping of the Eurasian badger (Meles meles) using faecal DNA. Mol Ecol 12:1649-1661

Frantzen MAJ, Silk JB, Ferguson JWH, Wayne RK, Kohn MH (1998) Empirical evaluation of preservation methods for faecal DNA. Mol Ecol 7:1423-1428

Gagneux P (1997) Furtive mating in female chimpanzees. Nature 387:358-359

Gerloff U, Schlötterer C, Rassmann K, Rambold I, Hohmann G, Fruth B, Tautz D (1995) Amplification of hypervariable simple sequence repeats (microsatellites) from excremental DNA of wild living bonobos (Pan paniscus). Mol Ecol 4:515-518

Goossens B, Chikhi L, Utami SS, Ruiter de J, Bruford MW (2000) A multi-samples, multi-extracts approach for microsatellite analysis of faecal samples in an arboreal ape. Conserv Genet 1:157-162

Goossens B, Waits LP, Taberlet P (1998) Plucked hair samples as a source of DNA: reliability of dinucleotide microsatellite genotyping. Mol Ecol 7:1237-1241 
Hoffman JI, Amos W (2005) Microsatellite genotyping errors: detection approaches, common sources and consequences for paternal exclusion. Mol Ecol 14:599-612

Höss M, Kohn M, Pääbo S, Knauer F, Schröder W (1992) Excrement analysis by PCR. Nature 359:199

Huber S, Bruns U, Arnold W (2003) Genotyping herbivore feces facilitating their further analyses. Wildlife Soc Bull 31: 692-697

Idaghdour Y, Broderick D, Korrida A (2003) Faeces as a source of DNA for molecular studies in a threatened population of great bustards. Conserv Genet 4:789-792

Kohn M, Knauer F, Stoffella A, Schröder W, Pääbo S (1995) Conservation genetics of the European brown bear - a study using excremental PCR of nuclear and mitochondrial sequences. Mol Ecol 4:95-103

Kohn MH, York EC, Kamradt DA, Haught G, Sauvajot RM, Wayne RK (1999) Estimating population size by genotyping faeces. Proc R Soc London B 266:657-663

Kruglyak S, Durrett RT, Schug MD, Aquadro CF (1998) Equilibrium distributions of microsatellite repeat length resulting from a balance between slippage events and point mutations. Proc Natl Acad Sci USA 95:10774-10778

Lathuillière M, Ménard N, Gautier-Hion A, Crouau-Roy B (2001) Testing the reliability of noninvasive genetic sampling by comparing analyses of blood and fecal samples in Barbary Macaques (Macaca sylvanus). Am J Primatol 55:151-158

Launhardt K, Epplen C, Epplen JT, Winkler P (1998) Amplification of microsatellites adapted from human systems in faecal DNA of wild Hanuman langurs (Presbytis entellus). Electrophoresis 19: $1356-1461$

Lucchini V, Fabbri E, Marucco F, Ricci S, Boitani L, Randi E (2002) Noninvasive molecular tracking of colonizing wolf (Canis lupus) packs in the western Italian Alps. Mol Ecol 11:857-868

Miller CR, Waits LP (2003) The history of effective population size and genetic diversity in the Yellowstone grizzly (Ursus arctos): implications for conservation. Proc Natl Acad Sci USA 100:4334-4339

Miller CR, Joyce P, Waits LP (2002) Assessing allelic dropout and genotype reliability using maximum likelihood. Genetics 160:357-266

Monteiro L, Bonnemaison D, Vekris A, Petry KG, Bonnet J, Vidal R, Cabrita J, Mégraud F (1997) Complex polysaccharides as PCR inhibitors in feces: Helicobacter pylori model. J Clin Microbiol 35:995-998

Morin PA, Chambers KE, Boesch C, Vigilant L (2001) Quantitative polymerase chain reaction analysis of DNA from noninvasive samples for accurate microsatellite genotyping of wild chimpanzees (Pan troglodytes verus). Mol Ecol 10:1835-1844

Mowat G, Strobeck C (2000) Estimating population size of grizzly bears using hair capture, DNA profiling, and mark-recapture analysis. J Wildlife Manage 64:183-193

Murphy MA, Waits LP, Kendall KC (2000) Quantitative evaluation of fecal drying methods for brown bear DNA analysis. Wildlife Soc Bull 28:951-957

Murphy MA, Waits LP, Kendall KC, Wasser SK, Higbee JA, Bogden R (2002) An evaluation of long-term preservation methods for brown bear (Ursus arctos) faecal DNA samples. Conserv Genet 3:435-440

Murphy MA, Waits LP, Kendall KC (2003) The influence of diet on faecal DNA amplification and sex identification in brown bears (Ursus arctos). Mol Ecol 12:2261-2265

Nievergelt CM, Mutschler T, Feistner ATC, Woodruff DS (2002) Social system of the Alaotran Gentle Lemur (Hapalemur griseus alaotrensis): genetic characterization of group composition and mating system. Am J Primatol 57:157-176

Paetkau D (2003) An empirical exploration of data quality in DNAbased population inventories. Mol Ecol 12:1375-1387
Palomares F, Godoy JA, Piriz A, O’Brien SJ, Johnson WE (2002) Faecal genetic analysis to determine the presence and distribution of elusive carnivores: design and feasibility for the Iberian lynx. Mol Ecol 11:2171-2182

Paradis E, Claude J (2002) Analysis of comparative data using generalized estimating equations. J Theor Biol, 218:175-185

Paradis E, Strimmer K, Claude J, Gangolf J, Opgen-Rhein R, Dutheil J, Noel Y, Bolker B (2005) ape: Analyses of Phylogenetics and Evolution. R package version 1.8

Parsons KM (2001) Reliable microsatellite genotyping of dolphin DNA from faeces. Mol Ecol 1:341-344

Piggott MP, Taylor AC (2003) Remote collection of animal DNA and its applications in conservation management and understanding the population biology of rare and cryptic species. Wildlife Res 30:1-13

Reed JZ, Tollit DJ, Thompson PM, Amos W (1997) Molecular scatology: the use of molecular genetic analysis to assign species, sex and individual identity to seal faeces. Mol Ecol 6:225-234

Roon DA, Waits LP, Kendall KC (2003) A quantitative evaluation of two methods for preserving hair samples. Mol Ecol Notes 3:163166

Sefc KM, Payne RB, Sorenson MD (2003) Microsatellite amplification from museum feather samples: effects of fragment size and template concentration on genotyping errors. Auk 120:982-989

Sloane MA, Sunnucks P, Alpers D, Beheregaray LB, Taylor AC (2000) Highly reliable genetic identification of individual northern hairy-nosed wombats from single remotely collected hairs: a feasible censusing method. Mol Ecol 9:1233-1240

Smith KL, Alberts SC, Bayes MK, Bruford MW, Altmann J, Ober C (2000) Cross-species amplification, non-invasive genotyping, and non-mendelian inheritance of human STRPs in savannah baboons. Am J Primatol 51:219-227

Taberlet P, Luikart G (1999) Non-invasive genetic sampling and individual identification. Biol J Linnean Soc 68:41-55

Taberlet P, Waits LP, Luikart G (1999) Noninvasive genetic sampling: look before you leap. Trends Ecol Evol 14:323-327

Valière N, Taberlet $P(2000)$ Urine collected in the field as a source of DNA for species and individual identification. Mol Ecol 9:2150 2152

Valière N, Berthier P, Mouchiroud D, Pontier D (2002) GEMINI: software for testing the effects of genotyping errors and multitubes approach for individual identification. Mol Ecol Notes 2:83-86

Valière N, Fumagalli L, Gielly L, Miquel C, Lequette B, Poulle M-L, Weber J-M, Arlettaz R, Taberlet P (2003) Long-distance wolf recolonization of France and Switzerland inferred from noninvasive genetic sampling over a period of 10 years. Anim Conserv 6:83-92

Vege S, McCracken GF (2001) Microsatellite genotypes of big brown bats (Eptesicus fuscus: Vespertilionidae, Chiroptera) obtained from their feces. Acta Chiropterol 3:237-244

Vigilant L (1999) An evaluation of techniques for the extraction and amplification of DNA from naturally shed hairs. Biol Chem 380: $1329-1331$

Vigilant L (2002) Technical challenges in the microastellite genotyping of a wild chimpanzee population. Evol Anthropol Suppl $1: 162-165$

Vigilant L, Hofreiter M, Siedel H, Boesch C (2001) Paternity and relatedness in wild chimpanzee communities. Proc Natl Acad Sci USA 98:12890-12895

Walsh PS, Metzger DA, Higuchi R (1991) Chelex 100 as a medium for simple extraction of DNA for PCR based typing from forensic material. Biotechniques 10:506-513

Wasser SK, Houston CS, Koehler GM, Cadd GG, Fain SR (1997) Techniques for application of faecal DNA methods to field studies of Ursids. Mol Ecol 6:1091-1097 
Wattier R, Engel CR, Saumitou-Laprade P, Valero M (1998) Short allele dominance as a source of heterozygote deficiency at microsatellite loci: experimental evidence at the dinucleotide locus Gv1CT in Gracilaria gracilis (Rhodophyta). Mol Ecol 7: 1569-1573

Whittier CA, Dhar AK, Stem C, Goodall J, Alcivar-Warren A (1999) Comparison of DNA extraction methods for PCR amplification of mitochondrial cytochrome c oxidase subunit II (COII) DNA from primate fecal samples. Biotechnol Techniq 13:771-779

Woods JG, Paetkau D, Lewis B, McLellan B, Proctor M, Strobeck C (1999) Genetic tagging of free-ranging black and brown bears. Wildlife Soc Bull 27:616-627 